\title{
Optional Treatment with Homeopathy for Children Suffering from Cancer
}

Erfried Pichler

Head of the Homeopathic Clinic of Paediatric Oncology at Klinikum Klagenfurt, Austria

\begin{tabular}{|c|c|}
\hline \multirow{4}{*}{$\begin{array}{l}\text { Abstract } \\
\text { Homeopathy is medicine for the individual person. In this article I present the treatment of a young } \\
\text { girl, suffering from Burkitt's lymphoma with her ups and downs and in the end with a satisfying outcome. } \\
\text { Homeopathic medicine is used in addition to conventional medicine. }\end{array}$} & Publication History: \\
\hline & Received: October 13, 2016 \\
\hline & Published. December 13,2016 \\
\hline & \\
\hline & Keywords: \\
\hline & $\begin{array}{l}\text { Bowel hyperechogenicity, } \\
\text { Congenital syphilis, Necrotising } \\
\text { enterocolitis, Prematurity }\end{array}$ \\
\hline
\end{tabular}

For twenty years, since November 1997, I have had the opportunity to treat children suffering from cancer with classical homeopathy in addition to conventional oncotherapy. During the first year only forty percent of the patients used this voluntary offer. However, two years later, all the patients took the opportunity to do so. Since that time, homeopathic treatment has been a fixed part of the oncological therapy regime at the Paediatric Oncology Department at Klinikum Klagenfurt, Austria, Europe. The Department's Head, Professor Dr. Wilhelm Kaulfersch, allowed this experiment due to his knowledge that at least seventy percent of the patients use a Complementary Medicine, but often not using a high quality procedure. So he decided to open the treatment to homeopathy which is under the control of his department. The financing is secured by the Kärntner Kinderkrebshilfe, (Carinthian Children's Cancer Support) a nonprofit organisation. Once a week I consult the inpatients and treat them with homeopathic remedies in addition to conventional therapy, mostly chemotherapy. The population of the province of Kärnten/Carinthia is 550,000 which is the reason why we treat approximately 15 children per year. Patients who need special therapy like stem cell therapy or special surgery in bone or brain cancer are transferred to Graz, Styria or to Vienna, the capital of Austria. The cooperation is commendable and we hold regular meetings to discuss our patients. That is how we reduce the costs for analgesic and psychotropic drugs. Homeopathic remedies also have a strong affect on the psychic situation of the young patients, through which greater tranquillity in the patients is recognisable.

Homeopathy is a medical science developed by Dr. Samuel Hahnemann (1755-1843), a German physician. It is based on the principle that like cures like. In simple words, it means that any substance, which can produce symptoms in a healthy person, can cure similar symptoms in a person who is sick [1]. This idea is referred to as the Law of Similars, and was understood by Aristotles and Hippocrates and mentioned in ancient Hindu manuscripts. It was Hahnemann, however, who turned it into a science of healing. A second principle of homeopathy is that you should give the least amount of medicine necessary to evoke a healing response. The World Health Organization estimates that homeopathy is used by 500 million people worldwide, making it the second most widely used medicine in the world. 45.000 MDs in Europe practice homeopathy with varying intensity and many of us combine it in special situations with conventional therapies. In India 250,000 MDs are registered and there is also an independent ministry for Ayurveda and Homeopathic Medicine. Homeopathy is used worldwide [2,3].
The Classical Homeopathic treatment consisted/consists? of individualized remedies, prescribed after careful anamnesis and repertorisation, following the rules of Samuel Hahnemann, the founder of homeopathy, to a greater or lesser extent [4]. In Austria only Medical Doctors are allowed to treat patients homeopathically. We use plants, minerals, and various tiny substances from animals. The further process of the mother tinctures are dilution and succussion, which is known as potentization.

If you want to produce a C 1- potency you take one drop of the mother tincture and add 99 drops of a solution, mostly $45 \%$ alcohol, succuss it and you get this C 1- potency. If you want a higher potency you have to repeat this procedure until you reach the requested potency.

Every now and then, for some inexplicable reason, there are attacks from groups with poor or no knowledge of homeopathy. Here is an example, the Australian Report from 2015. The documentation of the re-analysis of the Australian report into the question of what was done to show that homeopathy is not effective, produced the answer that the Australian overview was done twice: the first one showing that homeopathy is effective being hidden from the public in 2013 and based on the analysis of 176 trials $[5,6]$. The advisory committee was chaired by a member of a well-known anti-homeopathy group and high quality trials were excluded due to a patient number lower than 150 or other unknown reasons, and only FIVE trials gave the conclusion! that homeopathy does not work better than a placebo. Professor Hahn, an independent MD from Sweden, wrote in his review of homeopathic trials in 2015: to claim that homeopathy is only as effective as placebos, more than $90 \%$ of homeopathic trials have to be excluded.

Dr. Samuel Hahnemann: The physician's high and only mission is to restore the sick to health, to cure, as it is termed.

"Corresponding Author: Dr. Erfried Pichler, Head of the Homeopathic Clinic of Paediatric Oncology at Klinikum Klagenfurt, Austria; E-mail: erfried.pichler@medway.at

Citation: Pichler E (2017) Optional Treatment with Homeopathy for Children Suffering from Cancer. Int $\mathrm{J}$ Pediatr Neonat Care 2: 130. doi: https://doi. org/10.15344/2455-2364/2017/130

Copyright: @ 2017 Pichler. This is an open-access article distributed under the terms of the Creative Commons Attribution License, which permits unrestricted use, distribution, and reproduction in any medium, provided the original author and source are credited. 
Now I wish to present to you the case of a three-year old girl named Jana, born February 2011, who suffered from a diffuse, mature-cell B-Non Hodgkin Burkitt-like Lymphoma (5\% of ALL and high risk). This diagnosis was established on 2014-08-14. Normally fifty percent of the patients with that diagnosis can be cured, but that is not the case for diffuse mature-cell B-NHBL. The usual therapy is the CHOP schema plus Methotrexat. (C: cyclophosphamide, H: Hydroxydaunorubicin, O: Vincristine like Oncovin ${ }^{\circ}$, P: Prednisolone) 2014-08-16: The chemotherapy began and very soon side effects appeared: Stomatitis ulcerosa and infection of the lung with shock: resulting in one week in the intensive care unit and put into an artificial coma until 201409-15.

In homeopathy we know approximately thirty remedies which are useful in the therapy of Mb. Hodgkin. The main remedies are Acidum arsenicosum, Calcium fluoricum, Ceanothus, Kali salts, Natrium chloratum, Scrophularia nodosa and many more $[7,8]$.

How to find the specific homeopathic remedy? The basis is the individual anamnesis, which includes the whole biography, former and current complaints, and lasts at least one hour. The specific symptoms, related to the patient, have to be summarized and compared with the well known mode of action of these remedies. We are assisted by a repertory in which we see all remedies related to sickness symptoms [9]. That is the way to find the individualized homeopathic remedy to help the patient. This medicine is given as the basic treatment. If any side effects during the oncotherapy appear, acute remedies are necessary in addition. This regime has proved to be successful for delivery in C 30 , one to three times a day, five granules.

Now back to Jana and the whole individual anamnesis: Who is this girl?

Her mother grew up in Klagenfurt, my hometown in southern Austria, and now lives $700 \mathrm{kms}$ away in the mid west of Germany. Luckily I saw her daughter one year earlier when treating her viral infection with Ferrum phosphoricum, according to appropriate anamnesis and repertorisation [10].

She was a friendly, vivacious, blond, pale, delicate and graceful child. Her mother phoned me on 2014-09-14 and told me what had happened up to that point. With that knowledge I prescribed her Phosphorus LM 6 in the morning, Mercurius corrosivus C 12, 2 times and daily C 30 once, due to a temperature over $39^{\circ} \mathrm{C}$. Twenty hours later on 2014-09-15 she could be extubated [11]. It sounds like a coincidence but it isn 't. She stayed one more week in the ICU with full consciousness. Jana complained about faintness, nausea, vomiting and constipation. She got Strychnos nux vomica C 40 (provided by her mother). Phosphorus LM 6 as constitutional remedy in the morning is still the main remedy. She recovered very quickly and six days later, 2014-09-20, the 2nd Chemo - block started, because her condition was very good, which surprised the colleagues of the oncology department. Did a coincidence happen? No, not at all because in my 40 years of experience with homeopathy I am used to watching the process of an illness. If the situation changes in a clear way after giving the medicine, I am sure it's the effect of the remedy. Afterwards, from, the chemotherapy again nausea, loss of appetite and cramping pains in the middle of the abdomen. Two times Nux vomica $\mathrm{C} 40$ had no satisfying result [12]. Cadmium sulfuricum C 40 , also a proven drug in stomach problems reduced the complaints. Phosphorus LM 9 was the next prescription in the constitutional therapy on 2014-10-3. Under that regime no major side effects appeared during the $3 \mathrm{rd}$ and 4th Chemo - blocks. The 5th Chemo - block was feasible on 201411-26 and afterwards Jana became aggressive coupled with slight faintness: again she got Strychnos nux vomica C 30. An enormous anxiety appeared, especially at night with weakness, coldness, desire for warmth and burning stomach aches: these are leading symptoms from Acidum arsenicosum C 30.

14-12-07 three months after the first contact: Jana suffered with an infection with Clostridium difficile, which caused severe diarrhea and weakness. She was so listless that a transfer to the ICU was discussed. The additional therapy with Podophyllum, acidum arsenicosum and china officinalis resulted in normal stool next day. From 2014-1220 on the 6th Chemotherapy was administered. End of therapy in January 2015 [13]. For consolidation Jana took Phosphor LM 12, 1x week.

Example of a repertorisation, with Arsenicum album/ acidum arsenicosum in leading position is shown in the Figure 1.

Acute remedies are very often used to reduce the side effects of chemotherapy. For example, the treatment of stomatitis during chemotherapy and other helpful remedies:

Calendula C 30: tissue of mouth red, swollen and sore

Lachesis mutus: Ulcera, stomatitis aphthosa, blue-reddish. Touching aggravates

Mercurius solubilis: strong and tenacious salivation, putrid smell from the mouth. Burning pain, vesicles, blisters, aphthae and ulcers in the mouth. Irritability.

Mercurius corrosivus: plus very painful ulcers and worse condition. Very often used!

Acidum arsenicosum C 30: 1-3x5 granules: severe stomatitis, burning aches, warmth ameliorates, restlessness; fears of death, being alone, etc.

Strychnos nux vomica C 30: Incontrollable irritability, and lamentations, complaints and cries. Abuses persons. Nausea and vomiting. Alternate constipation and diarrhea - after abuse of medication $=$ this means side effects!

\section{Alfalfa C 12, 2x5 granules: loss of appetite}

But that is not the end. Jana had recurrent acute infections until April 2015, even though she was in a good mood. From here on this report is only a brief summary of our nearly daily contact. Horror diagnosis on 2015-05-07: Relapse of B-Non Hodgkin Burkitt like Lymphoma in lung, liver, spleen and abdomen. A very specific homeopathic substance against Morbus Hodgkin is Scrophularia nodosa. So the therapy had to be changed on 2015-05-15 to Phosphor LM 9, Scrophularia nodosa C 30 and intensive chemotherapy. Severe side effects appeared with tachycardia, nausea and many more $[14,15]$.

The situation on 2015-05-25: very weak condition but happy when in contact with the hospital nurse; severe abdominal pains around umbilicus, green, bloody stool. Bronchitis, inflammation of mouth mucosal with bloody discharge, for which she got Mercurius corrosivus C12. But five days later, on 2015-05-30 kidney insufficiency occurred. Furosemid was the proper therapy. The condition got worse, vomiting of bile occurred and the heart frequency was still around 150 and 40 breaths per minute. The stool was green and bloody and the blood count very low. Doctors gave her little chance of survival. But surprisingly a slow improvement during the next two weeks took place. 
Citation: Pichler E (2017) Optional Treatment with Homeopathy for Children Suffering from Cancer. Int J Pediatr Neonat Care 2: 130. doi: https:/doi. org/10.15344/2455-2364/2017/130

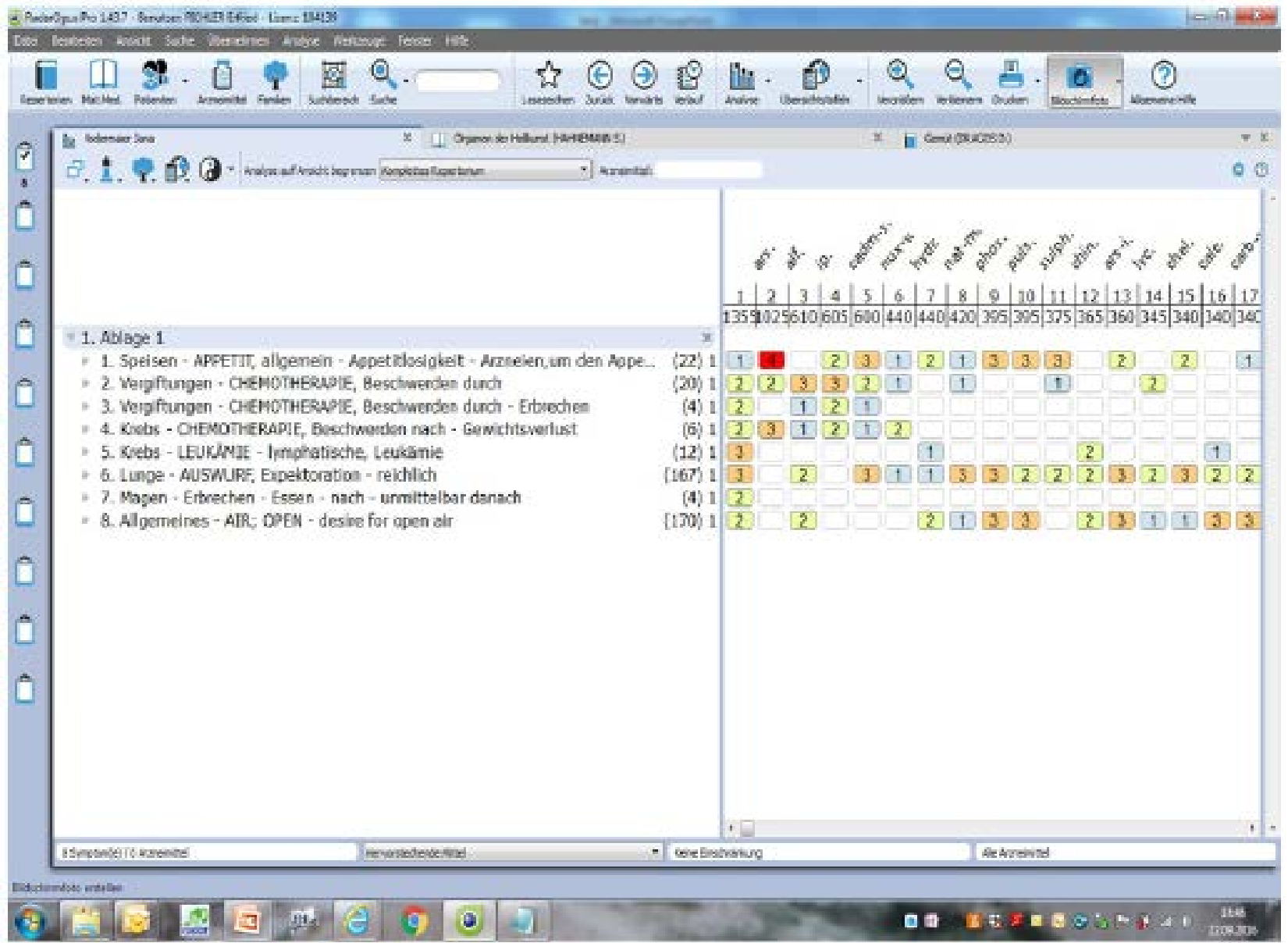

Figure 1: Repertorisation, with Arsenicum album/ acidum arsenicosum in leading position.

June 2015. Still tachycardia but the general condition was better and Jana was able to spend two nights at home! Again loss of appetite, weakness, despair, vomiting after eating and infection of the lung occurred. Desperation for everybody involved $[16,17]$.

Stem cell therapy was performed in August 2015. Afterwards there was a total loss of appetite with severe weakness, and she couldn't stand on her own feet. Anxiety was treated well with acidum arsenicosum. Energy increased but still loss of appetite: Alfalfa C 30, 1x/d. gave an improvement of appetite and no more artificial nutrition was necessary. Here we can see again how useful additional homeopathic medicine is.

End of September a CT of the lung described no pathology!

End of October 2015 discharged from hospital after six months!

In February 2016 the second stem cell transplantation (Booster effect) was carried out, this time without complications. One month later Jana attended a rehabilitation programme on the island of Sylt, where she made a very good recovery.

In August I met a blond, fair, friendly girl in my home town. If I hadn't know about her history, I wouldn't have had any idea about the severe illness she had gone through (in the past).

\section{Conclusion}

1. Homeopathy is a well proven and effective medical treatment

2. Together we are stronger.

3. That means, using Integrative Oncology: conventional therapy plus homeopathic medicine, which, once you try it, you will be convinced is worth the effort.

\section{Competing Interests}

The author declare that they he has no competing interests.

\section{References}

1. Erfried P (2003) Die homöopathische Behandlungsmöglichkeit an der Kinderonkologie im LKH Klagenfurt, Proceedings des Ligakongresses in Graz

2. Erfried $P(2004)$ Homöopathische Behandlung an der Kinderonkologie im LKH Klagenfurt

3. AHZ (Allgemeine Homöopathische Zeitung), Band 249: 62-70, Haug Verlag, Heidelberg

4. Erfried P (2005) Documenta Homoeopathica. Verlag W. Maudrich 15: 161201

5. Erfried P (2016) Documenta Homoeopathica. Verlag W. Maudrich 31: 97121,

6. RADAR Edition 10.5.003, Schroyens F., Synthesis, TE 2009 (D)

7. Phatak SR (1993) Materia medica of homeopathic medicines. B. Jain Publishers Ltd.

8. Vermeulen F (2006) Prisma, Das Arcanum der Materia Medica ans Licht gebracht, Auflage Emryss Verlag 
Citation: Pichler E (2017) Optional Treatment with Homeopathy for Children Suffering from Cancer. Int J Pediatr Neonat Care 2: 130. doi: https://doi. org/10.15344/2455-2364/2017/130

Page 4 of 4

9. Nash EB (2009) Leitsymptome in der homöopathischen Therapie, 2. aktualisierte Auflage, Haug Verlag

10. Erfried P (2003) The homeopathic treatment offered at the Children's Cancer Department in the Provincial Hospital, Klagenfurt. Proceedings of the League Congress in Graz.

11. Erfried P (2004) Homeopathic treatment offered at the Children's Cancer Department in the Provincial Hospital, Klagenfurt. AHZ (General Homeopathy Newspaper). Haug Publishers, Heidelberg 249: 62-70

12. Erfried P (2005) Documenta Homoeopathica. W. Maudrich Publishers 15: 161-201

13. Erfried P (2016) Documenta Homoeopathica. W. Maudrich Publishers 31: 97-121

14. RADAR Edition 10.5.003, Schroyens $F$ (2009) Synthesis, TE (D)

15. Phatak SR (1993) Materia medica of homeopathic medicines. B. Jain Publishers Ltd.

16. Vermeulen F (2006) Prisma, Spotlight on the Das Arcanum der Materia Medica edition, Emryss Publishers

17. Nash EB (2009) Leading symptoms in Homeopathic Medicine, 2. Updated edition, Haug Publishers 